\title{
LIABILITY FOR WORKPLACE INJURIES TO TRANS- NATIONAL EMPLOYEES IN AUSTRALIA: ISSUES AND CASE STUDIES
}

\author{
Brian C Williamson*
}

\begin{abstract}
Australia has workers' compensation laws creating compensation and other benefits for employees injured in the course of their employment. What happens if the injury occurs overseas? What arrangements are in place for foreign workers for perform work in Australia and are injured? Are these arrangements altered by Free Trade Agreements? This paper examines these issues.
\end{abstract}

INTRODUCTION

I. STATE/TERRITORIAL WORKERS' COMPENSATION LAWS-LOCAL

EMPLOYEES OF LOCAL EMPLOYERS OR FOREIGN EMPLOYERS

II. FOREIGN EMPLOYEES WORKING FOR LOCAL EMPLOYERS OR FOREIGN EMPLOYERS RECOGNISED IN AUSTRALIA................................................150

III. EMPLOYEES TRAVELLING OVERSEAS ON BEHALF OF LOCAL EMPLOYERS OR FOREIGN EMPLOYERS RECOGNISED IN AUSTRALIA 151

IV. FOREIGN EMPLOYEES TRAVELLING TO AUSTRALIA TO SEE LOCAL EMPLOYERS OR FOREIGN EMPLOYERS RECOGNISED IN AUSTRALIA ............154 V. FreE TRAde AgreEMENTS AND WORKERS' COMPENSATION RightS AND OBLIGATIONS 156

A. Australia \& the United States.................................................. 156

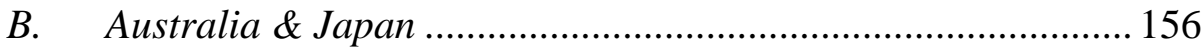
CONCLUSIONS 159

\section{INTRODUCTION}

In Australia, industrial relations and employment laws are organised at both the Federal and State/Territorial level, albeit it that, Federal jurisdiction is the most significant and far reaching.

The Federal jurisdiction's Fair Work Act 2009 (Cth) deals with such matters as the 10 minimum standards for all employees (called the "National Employment Standards"), anti-bullying arrangements, minimum working conditions (covered by the 122 Modern Awards, which regulate when work can be undertaken and penalty rates for work done outside the usual spread

\footnotetext{
* Managing Director, Williamson Legal, Sydney (www.williamsonlegal.com.au). Research fields: workplace strategy and corporate governance for employers. Brian acts for employers only and has particular interests in employment strategy and negotiations with unions for collective agreements.
} 
of hours) and the making of collective agreements.

The Federal jurisdiction also deals with the incorporation of local companies, the recognition of foreign companies who trade within Australia and also with the visa obligations for foreign employees working in Australia.

Each State/Territorial jurisdiction deals with such matters as minimum working ages, work health and safety and workers' compensation (although there is a Federal workers' compensation scheme for Federal employees and the military).

This means that:

(a) any local employer; or

(b) any foreign corporation/employer with foreign workers based in Australia or hiring locally based employees;

will need to be compliant with a range of Federal and State/Territory laws in respect of those employees.

This paper will deal with one such aspect of these compliance obligations.

\section{STATE/TERRITORIAL WORKERS' COMPENSATION LAWS-LOCAL} EMPLOYEES OF LOCAL EMPLOYERS OR FOREIGN EMPLOYERS

While each Australian jurisdiction has its own workers' compensation regime, each regime generally makes similar provisions for the local employees of both local and foreign employers who are injured or become ill in the course of their employment.

In other words:

(a) all local employers who hire local employees; and

(b) all foreign employers who hire local employees;

will need to take out workers' compensation insurance to ensure coverage for their employees. The premiums for such insurance is set by the various workers' compensation schemes. When that insurance is taken out, the employees will receive a broad range of insurance protections.

For example, in the State of NSW, the following arrangements apply:

(1) Compensation for "Injury" or "Illness" in the course of employment. Section 4 of the Workers' Compensation Act 1987 (NSW) defines injury as:

(a) means personal injury arising out of or in the course of employment;

(b) includes a disease injury, which means:

(i)a disease that is contracted by a worker in the course of employment but only if the employment was the main contributing factor to contracting 
the disease, and;

(ii) the aggravation, acceleration, exacerbation or deterioration in the course of employment of any disease, but only if the employment was the main contributing factor to the aggravation, acceleration, exacerbation or deterioration of the disease, and;

(c) does not include (except in the case of a worker employed in or about a mine) a dust disease, as defined by the Workers' Compensation (Dust Diseases) Act 1942, or the aggravation, acceleration, exacerbation or deterioration of a dust disease, as so defined.

Diseases contracted by workers are deemed to be work related. Section 19 of the Workers' Compensation Act 1987 (NSW) provides that:

(1) If a worker, during a time when the worker is engaged in employment of a kind prescribed by the regulations as an employment to which this subsection applies, contracts a disease prescribed by the regulations as a disease that is related to employment of that kind, then for the purposes of this Act, unless the contrary is established:

(a) the disease shall be deemed to have been contracted by the worker in the course of the employment in which the worker was so engaged, and;

(b) that employment shall be deemed to have been a substantial contributing factor to the disease.

Liability for injuries received by workers shall be the responsibility of the employer. Section 9 of the Workers' Compensation Act 1987 (NSW) provides that:

(1) A worker who has received an injury (and, in the case of the death of the worker, his or her dependants) shall receive compensation from the worker's employer in accordance with this Act.

(2) Compensation is payable whether the injury was received by the worker at or away from the worker's place of employment.

The conduct of the worker is generally irrelevant. Section 14 of the Workers' Compensation Act 1987 (NSW) provides that:

(1) Compensation is payable in respect of any injury resulting in the death or serious and permanent disablement of a worker, notwithstanding that the worker was, at the time when the injury was received:

(a) acting in contravention of any statutory or other regulation applicable to the worker's employment, or of any orders given by or on behalf of the employer, or;

(b) acting without instructions from the worker's employer.

if the act was done by the worker for the purposes of and in connection with the employer's trade or business.

(2) If it is proved that, an injury to a worker is solely attributable to the 
serious and wilful misconduct of the worker, compensation is not payable in respect of that injury, unless the injury results in death or serious and permanent disablement.

(3) Compensation is not payable in respect of any injury to or death of a worker caused by an intentional self-inflicted injury.

(4) Weekly compensation for loss of wages/remuneration up to $\$ 1,838.70$ per week (see s.34 of the Workers' Compensation Act 1987 $(N S W))$.

(5) Payment of medical and hospital expenses, ambulance and rehabilitation expenses (see ss.59-64A of the Workers' Compensation Act 1987 (NSW)).

(6) Funeral expenses for employees who have been killed whilst at work (see ss.26-28 of the Workers' Compensation Act 1987 (NSW)).

(7) Common law rights to sue for additional damages are preserved, provided that, no damages may be awarded unless the injury results in the death of the worker or in a degree of permanent impairment of the injured worker, that is at least $15 \%$ (see s.151H of the Workers' Compensation Act 1987 (NSW)).

\section{FOREIGN EMPLOYEES WORKING FOR LOCAL EMPLOYERS OR FOREIGN EMPLOYERS RECOGNISED IN AUSTRALIA}

For the most part, foreign workers who have been brought to Australia are reasonably treated. However, sadly, this is not always the case.

The Fair Work Ombudsman (created by the Fair Work Act 2009 (Cth)) has recently conducted an investigation in the actions of a foreign corporation that has been trading in Australia. According to media reports ${ }^{1}$, the investigation found that, Taiwanese company Chia Tung Development Corp Ltd employed 13 Chinese and 30 Filipino nationals aged between 20 to 50 years of age and brought them to Australiato install animal feed mills at sites in Narrabri, Manildra and Bomaderry in NSW.

The Filipino workers, who were on short stay visas and spoke no English, were paid around $\$ 9.00$ per hour after unlawful deductions were made. Acting Fair Work Ombudsman Michael Campbell said the workers were employed as electricians, welders and metal fabricators. The worked six days a week for nine to 11 hours each day. He said the Chinese workers were supposed to be paid about $\$ 10$ per hour, but received nothing for three months' work.

\footnotetext{
${ }^{1}$ Fair Work Ombudsman: Chinese and Filipino Workers Underpaid by Taiwanese Employer Chia Tung, SydNEY MoRning HeRALD, Apr. 21, 2015.
} 
Mr Campbell said:

"All they got was a $\$ 15.00$ a day food allowance".

"Chia Tung promised the Filipino workers about $\$ 27.00$ an hour, but subsequently unlawfully deducted thousands of dollars in fees from their wages - resulting in them getting just over $\$ 9.00$ an hour.”

This attention from the Fair Work Ombudsman arose from an earlier investigation into the Chia Tung Development Corporation Ltd. The WorkCover Authority of NSW reported on February 12, 2015²:

WorkCover is reminding businesses about their obligations to provide workers compensation policies for employees working under a section 457 visa.

Businesses failing to do so could be liable for covering the costs of a workers compensation injury or face a fine of up to $\$ 55,000$.

The reminder was prompted by a recent case where a Taiwan-based business, Chia Tung Development Corporation Ltd, employed around 45 international workers in NSW on s.457 visas without workers compensation policies.

WorkCover's Executive Director of Workers Compensation Regulation Caroline Walsh said employers' legal requirements, whether a sponsor company or a principal contractor to a sponsor company, were exactly the same.

"All companies involved with $\mathrm{s} .457$ visa workers are required under NSW law to have a policy of insurance for workers compensation from a licensed insurer, and to make sure they implement and maintain it," Ms Walsh said.

"If any person has entered into, or works under a contract of service with you - even if the contract is expressed or implied - then that person is considered a worker and you that person's employer.”

\section{EMPLOYEES TRAVELLING OVERSEAS ON BEHALF OF LOCAL EMPLOYERS OR FOREIGN EMPLOYERS RECOGNISED IN AUSTRALIA}

What is the position when a local employer or a foreign employer, recognised in Australia, sends employees overseas and they are injured or killed while away? This is not an unusual occurrence as the writer has discovered. In 2013, the Business Review Weekly reported ${ }^{3}$ :

Need to send a staff member on a trip? Send a woman. At a time when employers' responsibility for the wellbeing of travelling staff is increasing,

\footnotetext{
${ }^{2}$ Media Release 12/02/2015. Available at http://workcover.nsw.gov.au.

${ }^{3}$ Sending Staff Overseas? Women a Safer Bet Than Men, Michael Bleby RRW, Sep. 30, 2013.
} 
the less risky behavioural patterns of women create fewer potential liabilities for bosses - in terms of injury, work time lost and even death on the job.

Between 2009 and 2012, women accounted for just 27 per cent of all medical evacuations, 25 per cent of medical accidents, 30 per cent of medical sickness, according to analysis of the corporate traveller records of 50 large companies by medical and travel security risk services company International SOS.

In August, a typical month, SOS was involved with 21 so-called RMRs-repatriation of mortal remains-of male corporate travellers globally who died while overseas. There were no women.

...

Road accidents and petty crime are the two biggest risks facing both male and female corporate travellers, but the third and fourth-biggest risks for men are malaria and sexually-transmitted diseases, while for women they are travellers' diarrhoea and psychological stress, International SOS says.

The growing proportion of female business travellers-from about 10 per cent in 1975 to as high as 45 per cent today-is coinciding with legal changes that, in Australia are putting more of an onus on employers to provide a safe working environment for staff, even when they travel overseas, and during all parts of their trip. For employers, this means taking "all reasonably practicable steps" to minimise the risk of injury or other harm to the people who work for them.

For these employees, their employer has onerous obligations imposed upon them by the relevant State/Territory Work Health \& Safety Act. The workers' compensation laws of the State/Territory in which they work will continue to apply, even if they are overseas.

Section 10 of the Workers' Compensation Act 1987 (NSW) provides:

A personal injury received by a worker on any journey to which this section applies is, for the purposes of this Act, an injury arising out of or in the course of employment, and compensation is payable accordingly.

Subsection (1) does not apply if:

(a) the injury was received during or after any interruption of, or deviation from, any such journey, and

(b) the interruption or deviation was made for a reason unconnected with the worker's employment or the purpose of the journey,

unless, in the circumstances of the case, the risk of injury was not 
materially increased because of the interruption or deviation.

In Workers Compensation Nominal Insurer $v O^{4}$, the Workers Compensation Commission of NSW held that, an actor's employment was adequately connected with New South Wales for him to be entitled to workers compensation as a result of being injured while working overseas. Workforce Information ${ }^{5}$ reported that:

The claimant ruptured his Achilles tendon during a live performance in Bahrain on July 20, 2010. The injury required surgery, and the setback caused him temporary anxiety and depression. He was working under contract with MEI Live Ltd at the time, a company registered in Hong Kong.

Although the company was not insured in New South Wales, he applied for workers compensation under the Workers Compensation Act 1987 (NSW) from the Workers Compensation Nominal Insurer, on the basis that, his employment was connected with New South Wales according to s.9AA of the Act.

The nominal insurer disputed liability, contending the actor's employment was not connected with New South Wales because his contract had been made in Hong Kong. An arbitrator, however, found that, the actor was entitled to compensation, and made an award in his favour on October 16, 2013.

The nominal insurer appealed against the decision, and the Workers Compensation Commission examined whether the actor's employment was connected with New South Wales. MEI Live Ltd took no part in the appeal.

According to s.9AA(3), a series of three tests will determine whether an appropriate connection exists with New South Wales:

A worker's employment is determined to be connected with the state in which the worker usually works in that employment (the "usually works" test).

If the first test does not yield an answer, one must look for the state in which the worker is usually based for the purposes of the employment (the "usually based" test).

If the second test does not make the issue clear, one must look for the state in which the employer's principal place of business in Australia is located (the "principal place of business" test).

1. The "usually works" test

Relevant factors to consider included where the worker was contracted to work, the work history with the employer and the intention of the parties.

\footnotetext{
${ }^{4}$ NSWWCCPD 1 (January 16, 2014).

${ }^{5}$ Maria Karlsson-Lilas, Actor Injured Overseas—was Employment Connected with NSW? (February 13, 2014).
} 
Temporary employment arrangements for no longer than six months, on the other hand, should not be taken into account.

Under the current contract of employment, the actor had rehearsed in Sydney and performed in Bahrain, where he was injured. The contract had been made in Hong Kong, but that was not really relevant-it could have been made anywhere. His previous contracts with the company had seen him working in Dubai, Singapore and Jakarta.

The Commission found that, the arbitrator had erred in finding that the actor usually worked in New South Wales. The first test did not yield an answer.

2. The "usually based" test

The contract acknowledged that, the actor was based in Sydney, because it specified he was to be flown from Sydney to Bahrain and back to Sydney. The executive producer also lived in Sydney and conducted auditions and rehearsed performances there, which the actor had taken part in.

There was also a suggestion that, most of the fee paid to the actor had been paid into a bank account in Sydney.

The evidence was enough to satisfy the Commission that, the actor was based in Sydney.

3. The "principal place of business" test

Although it was not necessary to go through the third test in this case, the Commission included this step. It found that, although the company clearly was based in Hong Kong and produced shows that were performed in different countries in Asia, the Middle East and Australia, it engaged its executive producer in Sydney.

Auditions for the shows took place at her home office in Rozelle and rehearsals were held in Surry Hills. This was evidence that, the company conducted an integral part of its business in New South Wales. The third test also confirmed that, the actor's employment was connected with New South Wales.

\section{Foreign EMPloyees TRAVELLing TO Australia to SEe LoCAL EMPLOYERS OR FOREIGN EMPLOYERS RECOGNISED IN AUSTRALIA}

What is the situation when the CFO of say Mitsubishi visits Australia to see executives in his own company, other local employers or government officials? If he was injured while in NSW, is he able to claim workers' compensation coverage for that injury?

This is an important question as Australia's national medical insurance 
scheme, Medicare, does not cover a sponsored employee's medical costs. Medicare only comes into play if Australia has a reciprocal arrangement with other countries in relation to an employee's medical emergency expenses. The only employees entitled to full Medicare benefits are permanent residents.

Once again, reference must be had to s.9AA(5) of the Workers' Compensation Act 1987 (NSW), to assess the connection to NSW. For the sake of convenience, s.9AA states as follows:

Liability for compensation

Compensation under this Act is only payable in respect of employment that is connected with this State.

The fact that, a worker is outside this State when the injury happens does not prevent compensation being payable under this Act in respect of employment that is connected with this State.

A worker's employment is connected with:

(a) the State in which the worker usually works in that employment, or

(b) if no State or no one State is identified by paragraph (a), the State in which the worker is usually based for the purposes of that employment, or

(c) if no State or no one State is identified by paragraph (a) or (b), the State in which the employer's principal place of business in Australia is located.

In the case of a worker working on a ship, if no State or no one State is identified by subsection (3), a worker's employment is, while working on a ship, connected with the State in which the ship is registered or (if the ship is registered in more than one State) the State in which the ship most recently became registered.

If no State is identified by subsection (3) or (if applicable) (4), a worker's employment is connected with this State if:

(a) the worker is in this State when the injury happens, and

(b) there is no place outside Australia under the legislation of which the worker may be entitled to compensation for the same matter.

In deciding whether a worker usually works in a State, regard must be had to the worker's work history with the employer and the intention of the worker and employer. However, regard must not be had to any temporary arrangement under which the worker works in a State for a period of not longer than 6 months.

Compensation under this Act does not apply in respect of the employment of a worker on a ship if the Seafarers Rehabilitation and Compensation Act 1992 of the Commonwealth applies to the worker's employment. 
Returning to the injured CFO of Mitsubishi, he would probably reply on his country of origin's workers' compensation or medical insurance arrangements, but probably sub-section (6) and his work history would probably exclude him for coverage.

However, other foreign workers may be covered.

As can be seen from the example of the Chia Tung Development Corp Ltd cases referred to in Part 3 above, if the CFO's visit to Australia was prolonged, then workers' compensation insurance would have to be taken out.

\section{Free Trade AgreEMENTS AND WORKERS' COMPENSATION RigHTS AND OBLIGATIONS}

\section{A. Australia \& the United States}

Australia has free trade agreements with a number of countries, including New Zealand, Japan, Korea, Chile, USA, Malaysia, Singapore and Thailand. A number are under negotiation, including with India, Indonesia and the Trans Pacific Partnership.

The Australia-United States Free Trade Agreement (“AUSFTA"), which came into effect on January 1, 2005, ensures greater access to the United States market for Australian products. All tariffs have been eliminated for imported and exported products between the two countries.

The ASAFTA does not impact the above set out arrangements with respect to workers compensation for foreign workers entering Australia.

\section{B. Australia \& Japan}

According to the Australian Trade Commission website, Prime Ministers Tony Abbott and Shinzo Abe signed the Japan-Australia Economic Partnership Agreement ("JAEPA") on July 8, 2014, a landmark agreement set to strengthen ties with Australia's second-largest export market and the world's third-largest economy. The agreement came into force on January 15, 2015.

According to the Australian Trade Commission website key outcomes include:

- More than 97 per cent of Australia's exports to Japan will receive preferential access or enter duty-free when JAEPA is fully implemented.

- Two tariff cuts in quick succession: one on entry into force and one on April 1, 2015. Subsequent phased tariff reductions will also occur on April 1 each year. 
- Duty-free entry to Japan within ten years, for all our current resources, energy and manufacturing exports.

- JAEPA will help make Australia a more attractive destination for Japanese investment.

- JAEPA gives Australian agricultural producers and exporters a significant competitive advantage, and makes Australia the first major agricultural exporting economy to conclude such a liberalising agreement with Japan.

- JAEPA guarantees Australian services suppliers access to the significant and well-developed Japanese market in key areas of commercial interest, including financial, education, telecommunications and legal services and a range of other professional services.

Schedule 10 of the JAEPA makes a number of provisions with respect to Japanese workers coming to Australia. In particular:

\section{PART 1 \\ SPECIFIC COMMITMENTS OF AUSTRALIA}

1. Australia requires a natural person of Japan seeking entry and temporary stay in Australia under the provisions of Chapter 12 (Movement of Natural Persons) and this Annex to obtain, prior to entry, an appropriate visa or permit or other document or electronic authority granting entry and temporary stay and comply with any relevant requirements.

2. For the categories of specific commitments in Part 1 of this Annex, Australia shall not impose or maintain any limitations on the total number of visas to be granted to natural persons, in the form of numerical quotas or the requirement of an economic needs test.

Note: For the purposes of this Part, the term "actively operating" means that, the enterprise concerned is engaged in substantive business operations in Australia.

Section 1

Business Visitors of Japan

1. Entry and temporary stay shall be granted to a natural person of Japan referred to in subparagraph 3(a) for a period of up to 90 days.

2. Entry and temporary stay shall be granted to a natural person of Japan referred to in subparagraph 3(b) for a period of up to six months, with the possibility of further stay.

...

Section 2

Intra-Corporate Transferees of Japan

1. Entry and temporary stay shall be granted to an intra-corporate transferee of Japan referred to in subparagraph 3(a) for a period of up to four 
years, with the possibility of further stay.

2. Entry and temporary stay shall be granted to an intra-corporate transferee of Japan referred to in subparagraph 3(b) for a period of up to two years, with the possibility of further stay.

3. An intra-corporate transferee of Japan means an employee of an enterprise of Japan established in Australia through a branch, subsidiary or affiliate which is lawfully and actively operating in Australia, who is transferred to fill a position in the branch, subsidiary or affiliate of the enterprise in Australia, and who is:

(a) an executive or a senior manager, who is a natural person responsible for the entire or a substantial part of the operations of the enterprise in Australia, receiving general supervision or direction principally from higher level executives, the board of directors or stockholders of the enterprise, including directing the enterprise or a department or subdivision of it; supervising and controlling the work of other supervisory, professional or managerial employees; and having the authority to establish goals and policies of the department or subdivision of the enterprise; or

(b) a specialist, who is a natural person with advanced trade, technical or professional skills and experience who must be assessed as having the necessary qualifications, or alternative credentials accepted as meeting the domestic standards in Australia, for that occupation, and who must have been employed by the employer for not less than two years immediately preceding the date of the application for entry and temporary stay.

4. Entry and temporary stay of such a natural person who is seeking entry and temporary stay in accordance with paragraph 1 or 2 is subject to employer sponsorship. Full details of employer sponsorship requirements, including the list of eligible occupations for sponsorship, are available on the website of the Australian government department responsible for immigration matters. Employer sponsorship requirements and eligible occupations may change from time to time.

The JAEPA does not impact the above set out arrangements with respect to workers' compensation for foreign workers entering Australia. As occurred in the Chia Tung Development Corp Ltd cases referred to in Part 3 above, the Japanese companies would have to take out workers' compensation insurance for their workers employed in Australia. These workers are also entitled to be paid in accordance with the minimum requirements of the NES and any applicable industrial Modern Awards. 


\section{CONCLUSIONS}

Workers' compensation legislation coverage in Australia is organized on a state and territory basis, making it difficult for both local and foreign employers to standardize their insurance arrangements across the nation.

The workers compensation insurance obligations upon and the rights of employees of foreign companies, who travel to Australia to work are equally complex and Australia's various FTAs do not provide any solutions. Indeed, they can magnify the risks for employers.

Accordingly, it is recommended that, any employer sending workers to work in Australia:

(a) take out insurance to cover those travelling employees in the event of injury;

(b) decide whether they also need to take out workers' compensation insurance for employees transferred to Australia; and

(c) ensure that, all other workers' compensation legislative obligations are met.

Failure to do so, exposes the employer to many legal and commercial risks. 